\title{
Immunoregulation in human malaria: the challenge of understanding asymptomatic infection
}

\author{
Vitor R de Mendonça', Manoel Barral-Netto ${ }^{1,2} /+$ \\ ${ }^{1}$ Fundação Oswaldo Cruz, Centro de Pesquisas Gonçalo Moniz, Salvador, BA, Brasil \\ ${ }^{2}$ Universidade Federal da Bahia, Faculdade de Medicina, Salvador, BA, Brasil
}

\begin{abstract}
Asymptomatic Plasmodium infection carriers represent a major threat to malaria control worldwide as they are silent natural reservoirs and do not seek medical care. There are no standard criteria for asymptomatic Plasmodium infection; therefore, its diagnosis relies on the presence of the parasite during a specific period of symptomless infection. The antiparasitic immune response can result in reduced Plasmodium sp. load with control of disease manifestations, which leads to asymptomatic infection. Both the innate and adaptive immune responses seem to play major roles in asymptomatic Plasmodium infection; T regulatory cell activity (through the production of interleukin-10 and transforming growth factor- $\beta$ ) and B-cells (with a broad antibody response) both play prominent roles. Furthermore, molecules involved in the haem detoxification pathway (such as haptoglobin and haeme oxygenase-1) and iron metabolism (ferritin and activated c-Jun N-terminal kinase) have emerged in recent years as potential biomarkers and thus are helping to unravel the immune response underlying asymptomatic Plasmodium infection. The acquisition of large data sets and the use of robust statistical tools, including network analysis, associated with welldesigned malaria studies will likely help elucidate the immune mechanisms responsible for asymptomatic infection.
\end{abstract}

Key words: asymptomatic infection - immune response - biomarkers - networks

It is estimated that two-three billion people are at risk of contracting malaria, and nearly one million people die from this disease each year (WHO 2014). The spectrum of malarial disease can range from severe complications to a mild symptomatic infection to an asymptomatic carrier infection. Such distinct manifestations result from a combination of factors, including parasite virulence, host susceptibility, host immune response, disease tolerance mechanisms, and environmental factors (Andrade \& Barral-Netto 2011, Medzhitov et al. 2012).

Although there is no standard definition of asymptomatic plasmodial infection (API), individuals with API harbour the parasite as evidenced by positive parasitaemia. However, these individuals do not develop any symptoms during a defined period of time (Andrade \& Barral-Netto 2011, Lindblade et al. 2013). API is an significant obstacle to malaria eradication efforts and represents a serious healthcare problem for the following reasons: (i) serve as parasite reservoirs, which allow malarial disease to be maintained within a population over time as they can still transmit Plasmodium sp. to uninfected persons (Gouagna et al. 2004, Alves et al. 2005, Schneider et al. 2007, White 2008), (ii) asymptomatic carriers represent a serious risk to blood bank safety as

doi: 10.1590/0074-02760150241

Financial support: FIOCRUZ (407734/2012-0), CNPq (478527/2013-6)

MB-N is a senior investigator from CNPq.

+ Corresponding author: mbarral@bahia.fiocruz.br

Received 29 June 2015

Accepted 23 October 2015
API carriers can transmit malaria through blood transfusions (Najem \& Sulzer 2003, Fugikaha et al. 2007, Scuracchio et al. 2011, Anthony et al. 2013, Brouwer et al. 2013), and (iii) human immunodeficiency virus (HIV)-infected individuals with API sometimes exhibit increased viral load, which may enhance HIV transmission and accelerate disease progression and severity in endemic countries (Verhoeff et al. 1999, Whitworth et al. 2000, French et al. 2001, Kublin et al. 2005).

API can be attributed to several factors, including differences among Plasmodium sp. and host protective mechanisms. API is frequently associated with older people living in endemic areas as they are likely to have greater exposure to malaria and its vector in endemic settings over time, thus acquiring a partial immunity (Andrade et al. 2009, Ladeia-Andrade et al. 2009, Mendonça et al. 2013). In the same context, individuals who have had several previous episodes of symptomatic malaria are more likely to become asymptomatic carriers upon Plasmodium sp. infection (Andrade et al. 2009, Barbosa et al. 2014). Therefore, the immune response underlying asymptomatic infection still needs to be elucidated.

Individuals from endemic regions can acquire partial immunity to malarial parasites, and antidisease immunity may prevent the development of clinical symptoms of disease despite the presence or the number of parasites. Antiparasitic immunity (after a certain age) against Plasmodium sp. suppresses parasite load (Day \& Marsh 1991, Trape et al. 1994, Daubersies et al. 1996). The immune response in API is often described as disease resistance, which is associated with a reduction in pathogen burden; therefore, this protective mechanism reduces tissue damage and immunopathology related to malarial infection (Medzhitov et al. 2012). In contrast, some individuals can control disease manifestation despite not being able 
to reduce levels of parasitaemia; this phenomenon is described as disease tolerance (Medzhitov et al. 2012).

Immunity to malaria does not necessarily prevent infection; however, it does limit parasite density and symptoms (Tran et al. 2013). API individuals can remain infected for long periods even though asymptomatic subjects can develop symptomatic disease if they have a dysregulated immune response (Barbosa et al. 2014). Several studies have reported very low parasitaemia in individuals with API (Perkins et al. 2005, Minigo et al. 2009, Andrade et al. 2010b, Villasis et al. 2012), and many of them exhibited subpatent infections (i.e., infections undetected by microscopy) (Barbosa et al. 2014). Asymptomatic carriers who are not diagnosed with conventional malaria are a major challenge for malaria eradication in low-endemicity settings (Bousema et al. 2014). Taken together, these data illustrate the interaction between malarial immunity, parasitaemia, exposure, and malaria outcomes in endemic areas (Fig. 1).

The immune system seems to play a major role in malaria outcomes, and our object herein is to uncover the partial protective immune response to infection in API to unravel the mechanisms of disease resistance. Here, we review both innate and adaptive immune responses to Plasmodium infection as well as new approaches to understand API immunity.

Although not the main focus of this review, it is important to highlight that pathogen-related infections can modulate the immune response of individuals with malaria. In this context, asymptomatic infections have been reported to be composed of multiple genetically distinct Plasmodium sp. clones; multiclonal infections may be a marker of immunity and confer protection against malaria by inducing a broader immune response and tolerance to infection (Ntoumi et al. 1995, Felger et al. 1999, Smith et al. 1999, Rono et al. 2013). Regarding others pathogens, hepatitis B co-infection has been associated with Plasmodium vivax asymptomatic infection and may also boost the protective immune response (Andrade et al. 2011). Additionally, individuals co-infected with $P$. vivax and hepatitis B virus (HBV) have an increased HBV viraemia yet a decreased malaria parasitaemia (Andrade et al. 2011). These patients also have lower levels of pro-inflammatory tumour necrosis factor (TNF) and a lower interferon (IFN)- $\gamma /$ interleukin (IL)-10 ratio with higher levels of regulatory IL-10 (Andrade et al. 2011). Pre-existent filarial infection also seems to attenuate immune responses associated with severe Plasmodium falciparum malaria and protects against anaemia (Dolo et al. 2012). Co-infections with Ascaris lumbricoides or Schistosoma hematobium exhibit a trend towards a protective effect, whereas infections with hookworm or Schistosoma mansoni lead to aggravation of pathology and a higher incidence of malaria (Adegnika \& Kremsner 2012, Lemaitre et al. 2014).

Haemoglobinopathies, including haemoglobin $\mathrm{S}$ ( $\mathrm{HbS}$ ), haemoglobin $\mathrm{C}(\mathrm{HbC})$, and $\alpha$-thalassaemia, have been associated with protection from malaria (Mendonça et al. 2012a). API children with $\mathrm{HbS}$ and persistently positive smears exhibit a reduced median time for conversion to smear-negative responses (spontaneous clearance) than

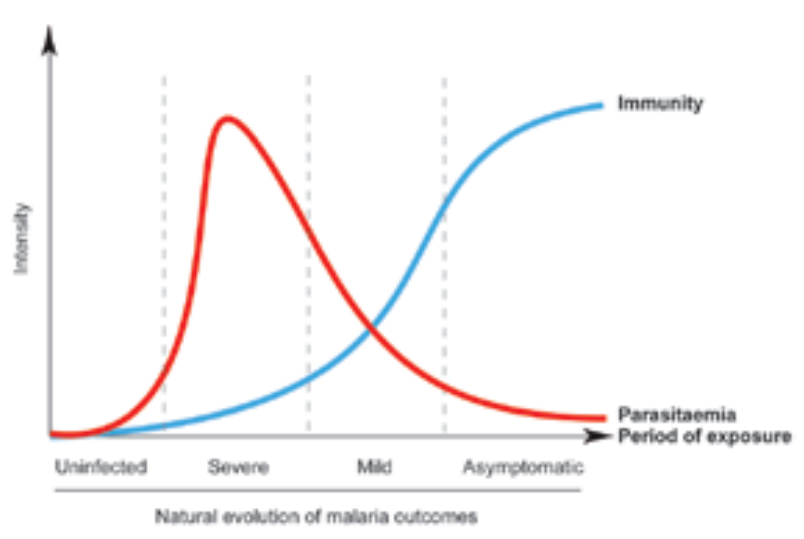

Fig. 1: understanding the natural evolution of malaria outcomes by parasitaemia, immunity, and period of exposure in endemic areas. In endemic settings, the natural evolution of malaria is initiated when uninfected individuals become infected for the first time, usually children who then develop a severe form of the illness. It is known that subjects with severe malaria have high parasitaemias and overall low protective immunity against malaria. In subsequent malarial infections, individuals initiate a more robust immune response against the parasites and exhibit lower levels of parasitaemia and milder forms of this disease. After many years of exposure to malaria and its vector, older people become resistant to malaria by exhibiting higher levels of antiparasitic immunity. Adapted from Andrade and Barral-Netto (2011).

do children without the haemoglobinopathy (Billo et al. 2012). Mechanisms by which haemoglobinopathies may attenuate the pathogenesis of malaria caused by $P$. falciparum include modulation of the inflammatory response and enhancement of cell-mediated and humoural immune responses through pathways that may include haeme oxygenase-1 (HO-1), reduced levels of cerebral chemokines, increased levels of nitric oxide, and higher IgG seroreactivity to P. falciparum antigens (Taylor et al. 2013). Other host erythrocyte polymorphisms also seem to influence the susceptibility to malaria. It has been demonstrated that $\alpha+$-thalassaemia (Oppenheimer et al. 1984, Enevold et al. 2007), southeast Asian ovalocytosis (Cattani et al. 1987, Foo et al. 1992), glucose-6-phosphate dehydrogenase (Mombo et al. 2003), and blood group O polymorphisms (Facer \& Brown 1979, Martin et al. 1979, Shimizu et al. 2005) are associated with protection from malaria by reducing parasitic densities.

\section{Innate immunity}

It has been reported that neutrophil antibody-dependent respiratory burst (ADRB) activity is correlated with acquired disease resistance to malaria in endemic regions (Joos et al. 2010). In this study, individuals with high ADRB indexes were 17-fold less susceptible to malaria attacks than those without high ADRB activity, and this ADRB activity was dependent on intact merozoites and $\operatorname{IgG}$ opsonins but not on parasitized erythrocytes or complement (Joos et al. 2010). Interestingly, the production of reactive oxygen species (ROS) by neutrophilic ADRB in response to $P$. falciparum an- 
tigen-specific IgGs was extracellular and indicated a key role for CD32/Fc $\gamma \mathrm{RII}$; however, the production of ROS in response to whole merozoites was almost completely within the cell, suggesting that the underlying mechanism was phagocytosis (Kapelski et al. 2014). The innate response to infected red blood cells ( $\mathrm{RBC})$ is also related to the functional activity of monocytes (MO) through their phagocytic activity, parasite killing through antibody-dependent cellular inhibition (ADCI), and supplying of peripheral tissues with macrophage and dendritic cells (DCs) (Chimma et al. 2009). Further, individuals with the $\mathrm{CD} 14^{\text {hi }} \mathrm{CCR} 2{ }^{+} \mathrm{CX} 3 \mathrm{CR} 1^{+} \mathrm{MO}$ subset and the highest mean levels of ADCI activity had lower blood parasitaemia levels, suggesting an antiparasitic activity associated with protection against malaria (Chimma et al. 2009). The induction and maintenance of B and T-cell responses requires functional DCs; these cells also have an important role in malaria immunity, and it was recently described that DCs from individuals with asymptomatic Plasmodium infection have higher expression of human leukocyte antigen-DR, which is required for antigen presentation (Kho et al. 2015). In a similar manner in a rodent model, DCs from nonlethal infections were fully functional and capable of secreting cytokines and stimulating T-cells compared to DCs from lethal infections, suggesting a major role for this cell in disease outcome and immunity (Wykes et al. 2007). Cells of the innate immune response are the first line of human defence against pathogens and may be important in control of the parasitaemia underlying cases of API.

\section{Adaptive immunity}

The innate immune system also helps direct the response of adaptive immune cells (B and T-cells) in recognising and binding diverse antigens through a repertoire of cell surface receptors (Palm \& Medzhitov 2009). It has been demonstrated that $\mathrm{CD}^{+}$and $\mathrm{CD}^{+} \mathrm{T}$-cells are important for malarial immunity in humans as well as in mouse models (Nussenzweig et al. 1967, Clyde et al. 1973, Schofield et al. 1987, Romero et al. 1989, Rodrigues et al. 1993, Tsuji et al. 1998, Hoffman \& Doolan 2000, Stephens et al. 2005, Overstreet et al. 2008, Schmidt et al. 2008, Roestenberg et al. 2009, 2011, Stephens \& Langhorne 2010, Friesen et al. 2010). In a clinical trial of the RTS,S/AS01E antimalarial vaccine, CD4 ${ }^{+}$ T-cell production of TNF, with or without IFN- $\gamma$, was a potential immunologic correlate of protection against disease in individuals from an endemic area (Olotu et al. 2011). $\mathrm{CD}^{+}$cells from individuals with fewer previous episodes of malaria were more inflammatory and had greater TNF production, whereas responses from $\mathrm{CD}^{+}$ T-cells from subjects with more frequent previous episodes of malaria were more typical of regulatory T-cells in that they produced IL-10 (Jagannathan et al. 2014). In this report, the absence of pro-inflammatory $\mathrm{CD}^{+} \mathrm{T}$ cells producing TNF was associated with asymptomatic infection (Jagannathan et al. 2014). Thus, it suggests that IL-10 production by T-helper $1 \mathrm{~T}$-cells may help prevent immunopathology by dampening the pro-inflammatory response (TNF) and preventing the development of clinical disease (Jagannathan et al. 2014).
$\mathrm{T}$ regulatory (Treg) cells $\left(\mathrm{CD}^{+} \mathrm{CD} 25^{+} \mathrm{FOXP} 3^{+}\right)$appear to mediate their effects by direct cell contact or by induction of the regulatory cytokines IL-10 or transforming growth factor (TGF)- $\beta$ (Thornton \& Shevach 2000, Powrie et al. 2003). Treg cells are induced following $P$. falciparum and $P$. vivax infection and are associated with a burst of TGF- $\beta$ production and decreased proinflammatory cytokine production (Walther et al. 2005, Gonçalves et al. 2010). Nevertheless, exposed asymptomatic controls (with or without parasitaemia) in a malariaendemic region of Indonesia had a lower frequency of Treg cells $\left(\mathrm{CD} 4^{+} \mathrm{CD} 25^{+} \mathrm{Foxp}^{+} \mathrm{CD} 127^{\mathrm{lo}}\right)$ than did patients with uncomplicated and severe malaria, suggesting a role for Treg reduction in malaria protection (Minigo et al. 2009). Intriguingly, increased expression of TNFRII, a marker of Treg activation, was found in Treg cells from API subjects when compared with uninfected individuals, a feature that might be important for survival of the parasites in asymptomatic carriers; however, TNFRII expression was not measured in patients with mild or severe malaria (Wammes et al. 2013). Congolese children with asymptomatic infection have a higher prevalence of polymorphisms in regulatory genes (STAT6 and IL10RA), which may influence Treg cells and malaria protection (Koukouikila-Koussounda et al. 2013).

The humoural response is also important for malaria protection because passive transfer of $\mathrm{IgG}$ from immune African adults to children and nonimmune adults with acute malaria rapidly reduces parasitaemia and abrogates fever (Cohen et al. 1961, Sabchareon et al. 1991). Not all exposure to malaria results in the generation of memory B-cells (MBCs) and IgG antibodies against $P$. falciparum are short-lived and fail to boost upon re-infection. Thus, immunological memory is a challenge in many vaccine trials (Dorfman et al. 2005, Bejon et al. 2006). Previous studies have described an atypical MBC population (characterised by the expression of FcRL4 and hyporesponsiveness) that is expanded in P. falciparum-exposed adults and children from Mali when compared with healthy United States of America controls, suggesting that this atypical population may contribute to the delayed acquisition and short-lived nature of malarial B-cell immunity (Weiss et al. 2009). Recently, it was described that atypical MBCs appear to differentiate from classical MBCs, and express a repertoire of inhibitory receptors and a deficient B-cell receptor signalling, which leads to impaired B-cell proliferation, cytokine production, and antibody secretion (Portugal et al. 2015). Other B-cells subtypes also seem to influence malaria resistance as Portugal et al. (2012) demonstrated that the percentage of activated MBCs and plasma cells was higher in the resistant Fulani ethnic group compared to those in the susceptible Dogon ethnic group, suggesting a role for B-cells in the protective immunity observed in the Fulani individuals. Individuals with asymptomatic infection tend to have higher titres of $P$. falciparum antigen-specific $\mathrm{IgG}$ than do individuals with other malaria outcomes. This higher response has been described as specific to several antigens, such as $P$. falciparum rifin on the surface of RBCs, recombinant protein fragments of $P$. falciparum rhoptry-associated 
protein-1, P. falciparum merozoite protein (C-terminal $10 \mathrm{kD}$ ), P. falciparum CLAG 9 (composed of 3 subunits named RhopH1, RhopH2, and RhopH3), and malariainfected erythrocyte variant surface antigens, including $P$. falciparum erythrocyte membrane protein $1, P$. falciparum merozoite surface protein 13D7 (MSP142), $P$. falciparum VarO rosetting variant, and $P$. falciparum erythrocyte binding-like and reticulocyte binding-like proteins (Alifrangis et al. 1999, Braga et al. 2002, Abdel-Latif et al. 2003, Kinyanjui et al. 2004, Villasis et al. 2012, Costa et al. 2013, Moormann et al. 2013, Sagna et al. 2013). Further, high antibody levels against glycosylphosphatidylinositols, the anchor molecules of some membrane proteins of Plasmodium species, is also observed more frequently in children with asymptomatic infections than in children with symptomatic infections in The Gambia (de Souza et al. 2002). Asymptomatic malaria carriers were also associated with high antibody levels against human brain antigens and Escherichia coli proteins as a result of polyclonal immunoglobin reactivity (Fesel et al. 2005). Furthermore, our group described that higher titre of IgG antibody against Anopheles darlingi mosquito saliva is also associated with immunity in asymptomatic $P$. vivax individuals from the Brazilian Amazon Region as a result of higher exposure to the malaria vector (Andrade et al. 2009). The intense production of antibodies in asymptomatic malaria carriers represents an active immune response and highlights the role of the humoural immune response in mediating disease resistance.

\section{Biomarkers}

A biomarker is any parameter that can be used as an indicator of a particular disease state or other physiological state and can be generally classified as either biomarkers for diagnosis or for disease severity (Andrade \& BarralNetto 2011). In the context of API, biomarkers can help investigators understand disease pathology by measuring important parameters in various immune pathways and may also be useful as markers of prognosis in either clinical or silent infection after Plasmodium sp. exposure (Laishram et al. 2012). In recent years, our group and others have been searching for human genetic factors and plasma measures related to the immune response associated with asymptomatic infection. However, none of these factors was sufficiently powerful to be a prognostic surrogate marker of clinical protection or disease susceptibility (Andrade \& Barral-Netto 2011, Mendonça et al. 2012b).

Laboratory measures are commonly used in medical practice as organ dysfunction parameters; individuals with asymptomatic $P$. vivax malaria have lower levels of aspartate aminotransferase (AST), alanine aminotransferase (ALT), indirect bilirubin, and serum creatinine as well as higher levels of $\mathrm{Hb}$ than do individuals with mild or severe symptomatic $P$. vivax malaria (Andrade et al. 2010b). TNF is a pro-inflammatory cytokine that has attracted special interest because of its ambiguous activity in host defence and in the pathogenesis of cerebral malaria and other severe complications (Kwiatkowski 2000). An increased TNF concentration is associated with symptoms of mild malarial pathogenesis (i.e., fever) as well as severe forms of infection, such as cerebral ma- laria (Kwiatkowski et al. 1990, Karunaweera et al. 1992). However, TNF- $\alpha$ has also been associated with the presence of potent antiparasitic activity as persistently elevated levels of this cytokine lead to rapid improvement of fever and reduction of parasitaemia (Mordmüller et al. 1997, Depinay et al. 2011). It is also noteworthy that patients with asymptomatic $P$. vivax malaria have lower levels of pro-inflammatory TNF and IFN- $\gamma$ and higher levels of IL-10, a trend which is proportional to disease severity (asymptomatic, mild, and severe) and which may explain the immunological control of clinical disease. However, parasite burden control may involve a more complex host response in addition to the moderation of TNF levels (Andrade et al. 2010b, Mendonça et al. 2013). In another setting in the Brazilian Amazon, it was found that asymptomatic carriers of low $P$. vivax parasitaemias also had lower levels of TNF and IFN- $\gamma$ than did symptomatic $P$. falciparum or $P$. vivax subjects (Gonçalves et al. 2012). Furthermore, certain combinations of genotypes in inflammatory-related genes $(D D X 39 B, T N F$ and IL6) are associated with a decreased risk of mild malaria compared to asymptomatic infection by reducing plasma levels of IL-6 and TNF (Mendonça et al. 2014).

The immune and organ dysfunction response during malaria may be a result, at least in part, of the harmful effects of free haem in the human host (Gozzelino et al. 2010). During parasite-induced intravascular haemolysis, great amounts of $\mathrm{Hb}$ are liberated; in the presence of superoxide and other ROS, $\mathrm{Hb}$ releases its haem prosthetic group (Bunn \& Jandl 1968, Hebbel et al. 1988, Pamplona et al. 2007, Ferreira et al. 2008). Free haem is a harmful molecule and can cause cytotoxicity, inflammation, oxidative stress, and even cell death (Ferreira et al. 2008, Gozzelino \& Soares 2011). Free haem levels exhibit a linear increase according to disease severity in asymptomatic $P$. vivax-infected subjects with the lowest haem plasma concentrations (Andrade et al. 2010a). In addition, haem is also elevated with malaria severity by $P$. falciparum, especially for cerebral malaria and acute renal failure subjects (Dalko et al. 2015). In addition to enhancing pro-inflammatory mechanisms, free haem during $P$. vivax malaria also impairs prostaglandin E2 (PGE2) and TGF- $\beta$ production through superoxide dismutase (SOD)1-dependent mechanism (Andrade et al. 2010a). SOD-1 is also elevated proportionally with disease severity in malaria patients and is useful for distinguishing mild and asymptomatic $P$. vivax cases by ROC curve analysis (Andrade et al. 2010c). In addition, asymptomatic carriers have higher concentrations of regulatory cytokines such as TGF- $\beta$ and PGE2 compared with mild and severe $P$. vivax patients, and TGF- $\beta$ and PGE2 are negatively correlated with SOD-1, which may be an additional defence mechanism against disease manifestation (Andrade et al. 2010a). In P. falciparum malaria, bicyclo-PGE2 is also elevated in asymptomatic patients compared with patients who have symptomatic disease (Perkins et al. 2005).

Over time, the human host has evolved protective mechanisms against the deleterious effects of free haem in the circulation. When $\mathrm{Hb}$ is released from ruptured RBC upon Plasmodium sp. infection, it is scavenged by haptoglobin (Hp) and prevents the release of haem. The 
complex $\mathrm{Hp}-\mathrm{Hb}$ is recognised by $\mathrm{CD} 163$ on the macrophage and hepatocyte surfaces in the spleen and liver, respectively (Philippidis et al. 2004, Quaye 2008). Free haem can also be scavenged by haemopexin, albumin, al-microglobulin, and high and low-density lipoproteins (Bunn \& Jandl 1966, Miller \& Shaklai 1999, Paoli et al. 1999, Allhorn et al. 2002, Fasano et al. 2007, Tolosano et al. 2010). Different Hp phenotypes are known to have different binding affinities for cell-free $\mathrm{Hb}$ (Hp1.1>Hp1.2>Hp2.2) and CD163 (Hp2.2>Hp1.2>Hp1.1) (Kristiansen et al. 2001). Our group has reported that individuals with the $H p 2$ allele are more likely to have symptomatic $P$. vivax malaria, and this group also has higher levels of $\mathrm{Hp}$ when compared with those of patients with asymptomatic infection. This probably represents a compensatory mechanism against the low binding affinity of $\mathrm{Hp} 2$ to free $\mathrm{Hb}$ (Mendonça et al. 2012b). The Hp2.2 phenotype has also been associated with a higher susceptibility to $P$. falciparum infection in the Dogon ethnic group living in Mali (Perdijk et al. 2013). Furthermore, soluble CD163 (sCD163) (marker of receptor activation) is also lower in asymptomatic patients when compared with that in symptomatic subjects, and a cut-off value of sCD163 may be used to distinguish between symptomatic and disease-free individuals (Mendonça et al. 2012b). In Mali, sCD163 was increased in $P$. falciparum infected individuals compared to uninfected subjects (Perdijk et al. 2013). Inside the cell, haem is degraded by $\mathrm{HO}-1$ to produce carbon monoxide (CO), labile iron, and biliverdin. In murine models, HO-1 affords protection against cerebral malaria by reducing neuroinflammation (including CD $8^{+} \mathrm{T}$-cell brain sequestration), and exposure to $\mathrm{CO}$ may reduce severe complications (Pamplona et al. 2007). HO-1 also seems to be one of the mechanisms by which sickle cell disease confers protection against experimental malaria (Ferreira et al. 2011). HO-1 plasma levels are higher in symptomatic cases (as compared to asymptomatic individuals) as a regulatory defence, and a microsatellite polymorphism (GT)n in HMOX1 regulates the expression of this enzyme (Mendonça et al. 2012b). In addition, high HO-1 levels and this microsatellite polymorphism were associated with severe malaria, including death, in another study (Walther et al. 2012). However, other studies also have demonstrated conflicting results and no association between this $H M O X 1$ microsatellite polymorphism and malaria severity (Kuesap et al. 2010, Hansson et al. 2015).

Iron is produced by haem catabolism and also obtained by dietary uptake; this metal is necessary for complete Plasmodium development (Gozzelino et al. 2010). However, intracellular labile iron is dangerous because it converts to a free radical unless it is scavenged by ferritin, which acts as a vital antioxidant molecule in several experimental models (Balla et al. 1992, Cozzi et al. 2000, Berberat et al. 2003). Ferritin serum levels are decreased and associated with anaemia in a population from the Brazilian Amazon exposed to P. vivax malaria; symptomatic individuals from this group infected with $P$. vivax have lower levels of ferritin, which are directly proportional to the hepatic damage score (Cardoso et al. 1994, Gozzelino et al. 2012). It has been reported that ferritin promotes disease resistance to malaria by preventing labile intracellular iron from sustaining pro-apoptotic c-Jun $\mathrm{N}$-terminal kinase activation, and this tolerance requires the expression of HO-1 (Gozzelino et al. 2012). Interestingly, malarial tolerance mediated by ferritin production is independent of the parasitaemia rate and represents a host defence strategy to limit the fitness costs of infection irrespective of pathogen burden (Medzhitov et al. 2012).

\section{New approaches to understanding asymptomatic infection}

In recent years, large amounts of data have become available as a result of the progress in technological methods, such as multiplex measurements, genome-wide genotyping, microarrays, RNAseq, and multicolour flow cytometry (Tran et al. 2012). Genome-wide studies allowed the discovery of important loci related to malaria resistance and low parasitaemia. Linkage of asymptomatic parasitaemia to 5q31-q33 has been reported in humans (Rihet et al. 1998, Timmann et al. 2007) and, recently, chromosomes $6 \mathrm{p} 21.3$ and $17 \mathrm{p} 12$ were correlated with resistance in individuals from Burkina Faso (Brisebarre et al. 2014). Equally important, the field of engineered humoural immunity (with the production of human monoclonal antibodies) has allowed a better understanding of the malaria immune response by facilitating several laboratory methods (i.e., multiparameter flow cytometry).

To understand this large volume of information, new approaches for data analysis have become more widespread and multivariate (clusters, principal component analysis, etc.), artificial neural, Bayesian, and network analysis methods are some tools that can be used to characterise a molecular signature of resistance or susceptibility to malaria (Jayavanth \& Singh 2003, Kiang et al. 2006, da Cunha et al. 2010, Bachtiar et al. 2013). Many studies have attempted to identify molecular signatures associated with severe P. falciparum malaria, but few have focused on the mechanisms behind asymptomatic Plasmodium infection (Timmann et al. 2007, 2012, Jallow et al. 2009, Milet et al. 2010). Using a network approach, our group recently described the interactions among cytokines, chemokines and other inflammatory proteins associated with different $P$. vivax malaria outcomes (Mendonça et al. 2013). Network analysis allows a better understanding of the inflammatory profile from different malaria groups by allowing easy visualisation of interactions between several markers and identification of patterns of association that may indicate susceptibility or disease tolerance signatures. Using network analysis, it has been demonstrated that patients with asymptomatic $P$. vivax malaria have an overall reduction in pro-inflammatory cytokines (TNF, IFN- $\gamma$, IL-6) and markers of tissue damage (ALT, AST, creatinine, bilirubin, and others) and augmented levels of regulatory cytokines (TGF- $\beta$ and IL-10) when compared with those of the symptomatic groups (mild and severe malaria) (Mendonça et al. 2013). Furthermore, IL-4 had the highest number of interactions between all the markers in the asymptomatic group, suggesting a possible role for this cytokine in mediating $P$. vivax malaria tolerance (Mendonça et al. 2013). Others studies have also used the same network 


Cells of the immune response

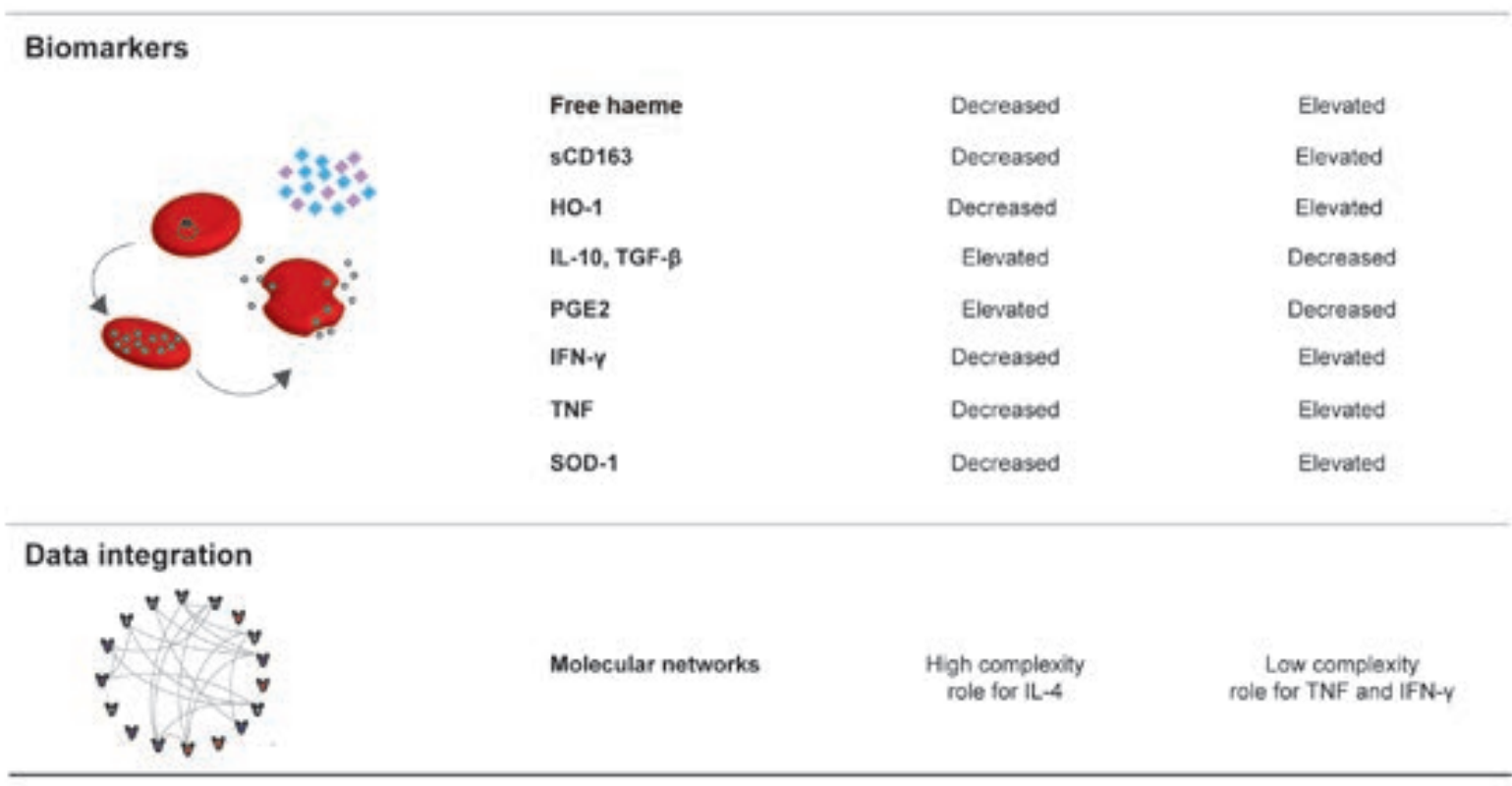

Fig. 2: the immune response underlying asymptomatic infection. Aspects of the immune response of asymptomatic malaria carriers were compared to symptomatic patients. This response was didactically divided into immune cells including T regulatory (Treg) cells, CD4+ T-cells, B-cells, neutrophils, and monocytes (MOs) and biomarkers related to inflammation [interleukin (IL)-10, transforming growth factor (TGF)- $\beta$, prostaglandin E2 (PGE2), interferon (IFN)- $\gamma$, and tumour necrosis factor (TNF) and the haeme pathway [haeme, soluble CD163 (sCD163), haeme oxygenase-1 (HO1), and superoxide dismutase (SOD)-1]. Additionally, molecular networks in the context of asymptomatic infection illustrate the use of methods of data integration in immunology. ADCI: antibody-dependent cellular inhibition; ADRB: antibody-dependent respiratory burst.

analysis for placental malaria and malarial anaemia, but none analysed asymptomatic infection (Ong'echa et al. 2011, Sikora et al. 2011). In this context, cohort studies with a large sample size and an extensive bioinformatics approach are highly necessary to better understand the interactions among the immune response pathways associated with asymptomatic infection tolerance.

\section{Concluding remarks}

It is noteworthy that API is related to clinical disease tolerance (i.e., absence of symptomatology) but is not associated with immunity and inflammatory tolerance. Asymptomatic $P$. vivax infection is an active and acquired state, and it can control parasitaemia and limit organ dysfunction by an as yet poorly understood immune mechanism. Asymptomatic individuals car- rying the parasite are natural reservoirs representing a challenge for malaria eradication, primarily in low and moderate-endemic countries. The use of mass drug administration or mass screening and treatment schemes is controversial (Tada et al. 2012). Overall, biomarkers related to the haem pathway and iron metabolism have emerged in recent years as potential clues to unravel the immune response of API. Despite this progress, there is no reliable marker of prognosis in API. Immune cells, especially Tregs and B-cells, seem to play an important role in protection from disease manifestation. Furthermore, it has been observed that the immune response in individuals with asymptomatic infection is usually associated with a lower pro-inflammatory and a higher regulatory production of biomarkers and host genetic alterations that may contribute to malaria tolerance. Nevertheless, 
the acquisition of large-scale biological data along with the use of robust bioinformatics tools, including a network approach, will help investigators to understand the immune response behind asymptomatic infection. The major topics described here are summarised in Fig. 2. Longitudinal studies of sequential episodes of malaria in the same individual are necessary to better understand the immune response of individuals with API who are able to clear their parasitaemia compared with those who are more likely to have a symptomatic disease or remain symptomless despite the presence of Plasmodium sp. With this understanding, better medical management of API carriers, the development of malarial vaccines, and strategies for malaria eradication will be facilitated.

\section{REFERENCES}

Abdel-Latif MS, Dietz K, Issifou S, Kremsner PG, Klinkert M-Q 2003. Antibodies to Plasmodium falciparum rifin proteins are associated with rapid parasite clearance and asymptomatic infections. Infect Immun 71: 6229-6233.

Adegnika AA, Kremsner PG 2012. Epidemiology of malaria and helminth interaction: a review from 2001 to 2011. Curr Opin HIV AIDS 7: 221-224.

Alifrangis M, Lemnge MM, Moon R, Theisen M, Bygbjerg I, Ridley RG, Jakobsen PH 1999. IgG reactivities against recombinant rhoptry-associated protein-1 (rRAP-1) are associated with mixed Plasmodium infections and protection against disease in Tanzanian children. Parasitology 119: 337-342.

Allhorn M, Berggård T, Nordberg J, Olsson ML, Akerström B 2002. Processing of the lipocalin alpha(1)-microglobulin by hemoglobin induces heme-binding and heme-degradation properties. Blood 99: 1894-1901.

Alves FP, Gil LHS, Marrelli MT, Ribolla PEM, Camargo EP, da Silva LHP 2005. Asymptomatic carriers of Plasmodium spp as infection source for malaria vector mosquitoes in the Brazilian Amazon. J Med Entomol 42: 777-779.

Andrade BB, Araújo-Santos T, Luz NF, Khouri R, Bozza MT, Camargo LMA, Barral A, Borges VM, Barral-Netto M 2010a. Heme impairs prostaglandin E2 and TGF-beta production by human mononuclear cells via $\mathrm{Cu} / \mathrm{Zn}$ superoxide dismutase: insight into the pathogenesis of severe malaria. J Immunol 185: 1196-1204.

Andrade BB, Barral-Netto M 2011. Biomarkers for susceptibility to infection and disease severity in human malaria. Mem Inst Oswaldo Cruz 106 (Suppl. I): 70-78.

Andrade BB, Reis-Filho A, Souza-Neto SM, Clarêncio J, Camargo LMA, Barral A, Barral-Netto M 2010b. Severe Plasmodium vivax malaria exhibits marked inflammatory imbalance. Malar J 9: 13.

Andrade BB, Reis-Filho A, Souza-Neto SM, Raffaele-Netto I, Camargo LMA, Barral A, Barral-Netto M 2010c. Plasma superoxide dismutase-1 as a surrogate marker of vivax malaria severity. PLoS Negl Trop Dis 4: e650.

Andrade BB, Rocha BC, Reis-Filho A, Camargo LMA, Tadei WP, Moreira LA, Barral A, Barral-Netto M 2009. Anti-Anopheles darlingi saliva antibodies as marker of Plasmodium vivax infection and clinical immunity in the Brazilian Amazon. Malar J 8: 121.

Andrade BB, Santos CJN, Camargo LM, Souza-Neto SM, Reis-Filho A, Clarêncio J, Mendonça VRR, Luz NF, Camargo EP, Barral A, Silva AAM, Barral-Netto M 2011. Hepatitis B infection is associated with asymptomatic malaria in the Brazilian Amazon. PLoS One 6: e19841.
Anthony CN, Lau Y-L, Sum J-S, Fong M-Y, Ariffin H, Zaw W-L, Jeyajothi I, Mahmud R 2013. Malaysian child infected with Plasmodium vivax via blood transfusion: a case report. Malar J 12: 308.

Bachtiar LR, Unsworth CP, Newcomb RD 2013. Application of artificial neural networks on mosquito olfactory receptor neurons for an olfactory biosensor. Conf Proc IEEE Eng Med Biol Soc 2013: 5390-5393.

Balla G, Jacob HS, Balla J, Rosenberg M, Nath K, Apple F, Eaton JW, Vercellotti GM 1992. Ferritin: a cytoprotective antioxidant strategem of endothelium. J Biol Chem 267: 18148-18153.

Barbosa S, Gozze AB, Lima NF, Batista CL, Bastos M da S, Nicolete VC, Fontoura PS, Gonçalves RM, Viana SAS, Menezes MJ, Scopel KKG, Cavasini CE, Malafronte R dos S, da Silva-Nunes M, Vinetz JM, Castro MC, Ferreira MU 2014. Epidemiology of disappearing Plasmodium vivax malaria: a case study in rural Amazonia. PLoS Negl Trop Dis 8: e3109.

Bejon P, Mwacharo J, Kai O, Mwangi T, Milligan P, Todryk S, Keating S, Lang T, Lowe B, Gikonyo C, Molyneux C, Fegan G, Gilbert SC, Peshu N, Marsh K, Hill AVS 2006. A Phase 2b randomised trial of the candidate malaria vaccines FP9 ME-TRAP and MVA ME-TRAP among children in Kenya. PLoS Clin Trials 1: e29.

Berberat PO, Katori M, Kaczmarek E, Anselmo D, Lassman C, Ke B, Shen X, Busuttil RW, Yamashita K, Csizmadia E, Tyagi S, Otterbein LE, Brouard S, Tobiasch E, Bach FH, Kupiec-Weglinski JW, Soares MP 2003. Heavy chain ferritin acts as an antiapoptotic gene that protects livers from ischemia reperfusion injury. FASEB J 17: 1724-1726.

Billo MA, Johnson ES, Doumbia SO, Poudiougou B, Sagara I, Diawara SI, Diakité M, Diallo M, Doumbo OK, Tounkara A, Rice J, James MA, Krogstad DJ 2012. Sickle cell trait protects against Plasmodium falciparum infection. Am J Epidemiol 176 (Suppl.): S175-S185.

Bousema T, Okell L, Felger I, Drakeley C 2014. Asymptomatic malaria infections: detectability, transmissibility and public health relevance. Nat Rev Microbiol 12: 833-840.

Braga EM, Barros RM, Reis TA, Fontes CJF, Morais CG, Martins MS, Krettli AU 2002. Association of the IgG response to Plasmodium falciparum merozoite protein (C-terminal $19 \mathrm{kD}$ ) with clinical immunity to malaria in the Brazilian Amazon Region. Am J Trop Med Hyg 66: 461-466.

Brisebarre A, Kumulungui B, Sawadogo S, Atkinson A, Garnier S, Fumoux F, Rihet P 2014. A genome scan for Plasmodium falciparum malaria identifies quantitative trait loci on chromosomes 5q31, 6p21.3, 17p12, and 19p13. Malar J 13: 198.

Brouwer EE, van Hellemond JJ, van Genderen PJ, Slot E, van Lieshout L, Visser LG, Wismans PJ 2013. A case report of transfusion-transmitted Plasmodium malariae from an asymptomatic non-immune traveller. Malar J 12: 439.

Bunn HF, Jand1 JH 1966. Exchange of heme among hemoglobin molecules. Proc Natl Acad Sci USA 56: 974-978.

Bunn HF, Jandl JH 1968. Exchange of heme among hemoglobins and between hemoglobin and albumin. $J$ Biol Chem 243: 465-475.

Cardoso MA, Ferreira MU, Camargo LM, Szarfarc SC 1994. Anaemia, iron deficiency and malaria in a rural community in Brazilian Amazon. Eur J Clin Nutr 48: 326-332.

Cattani JA, Gibson FD, Alpers MP, Crane GG 1987. Hereditary ovalocytosis and reduced susceptibility to malaria in Papua New Guinea. Trans R Soc Trop Med Hyg 81: 705-709.

Chimma P, Roussilhon C, Sratongno P, Ruangveerayuth R, Pattanapanyasat K, Pérignon J-L, Roberts DJ, Druilhe P 2009. A distinct peripheral blood monocyte phenotype is associated with parasite inhibitory activity in acute uncomplicated Plasmodium falciparum malaria. PLoS Pathog 5: e1000631. 
Clyde DF, Most H, McCarthy VC, Vanderberg JP 1973. Immunization of man against sporozite-induced falciparum malaria. Am J Med Sci 266: 169-177.

Cohen S, McGregor IA, Carrington S 1961. Gamma-globulin and acquired immunity to human malaria. Nature 192: 733-737.

Costa JDN, Zanchi FB, Rodrigues FLS, Honda ER, Katsuragawa TH, Pereira DB, Taborda RLM, Tada MS, Ferreira RGM, Pereirada-Silva LH 2013. Cross-reactive anti-PfCLAG9 antibodies in the sera of asymptomatic parasite carriers of Plasmodium vivax. Mem Inst Oswaldo Cruz 108: 98-105.

Cozzi A, Corsi B, Levi S, Santambrogio P, Albertini A, Arosio P 2000. Overexpression of wild type and mutated human ferritin $\mathrm{H}$-chain in HeLa cells: in vivo role of ferritin ferroxidase activity. J Biol Chem 275: 25122-25129.

da Cunha GB, Luitgards-Moura JF, Naves ELM, Andrade AO, Pereira AA, Milagre ST 2010. Use of an artificial neural network to predict the incidence of malaria in the city of Cantá, state of Roraima. Rev Soc Bras Med Trop 43: 567-570.

Dalko E, Das B, Herbert F, Fesel C, Pathak S, Tripathy R, Cazenave P-A, Ravindran B, Sharma S, Pied S 2015. Multifaceted roles of heme during severe Plasmodium falciparum infections in India. Infect Immun 83: 3793-3799.

Daubersies P, Sallenave-Sales S, Magne S, Trape JF, Contamin H, Fandeur T, Rogier C, Mercereau-Puijalon O, Druilhe P 1996. Rapid turnover of Plasmodium falciparum populations in asymptomatic individuals living in a high transmission area. Am J Trop Med Hyg 54: 18-26.

Day KP, Marsh K 1991. Naturally acquired immunity to Plasmodium falciparum. Immunol Today 12: A68-71.

de Souza JB, Todd J, Krishegowda G, Gowda DC, Kwiatkowski D, Riley EM 2002. Prevalence and boosting of antibodies to Plasmodium falciparum glycosylphosphatidylinositols and evaluation of their association with protection from mild and severe clinical malaria. Infect Immun 70: 5045-5051.

Depinay N, Franetich JF, Grüner AC, Mauduit M, Chavatte J-M, Luty AJF, van Gemert G-J, Sauerwein RW, Siksik J-M, Hannoun L, Mazier D, Snounou G, Rénia L 2011. Inhibitory effect of TNF- $\alpha$ on malaria pre-erythrocytic stage development: influence of host hepatocyte/parasite combinations. PLoS One 6: e17464.

Dolo H, Coulibaly YI, Dembele B, Konate S, Coulibaly SY, Doumbia SS, Diallo AA, Soumaoro L, Coulibaly ME, Diakite SAS, Guindo A, Fay MP, Metenou S, Nutman TB, Klion AD 2012. Filariasis attenuates anemia and proinflammatory responses associated with clinical malaria: a matched prospective study in children and young adults. PLoS Negl Trop Dis 6: e1890.

Dorfman JR, Bejon P, Ndungu FM, Langhorne J, Kortok MM, Lowe BS, Mwangi TW, Williams TN, Marsh K 2005. B-cell memory to 3 Plasmodium falciparum blood-stage antigens in a malariaendemic area. J Infect Dis 191: 1623-1630.

Enevold A, Alifrangis M, Sanchez JJ, Carneiro I, Roper C, Børsting C, Lusingu J, Vestergaard LS, Lemnge MM, Morling N, Riley E, Drakeley CJ 2007. Associations between alpha+-thalassemia and Plasmodium falciparum malarial infection in northeastern Tanzania. J Infect Dis 196: 451-459.

Facer CA, Brown J 1979. ABO blood groups and falciparum malaria. Trans R Soc Trop Med Hyg 73: 599-600.

Fasano M, Fanali G, Leboffe L, Ascenzi P 2007. Heme binding to albuminoid proteins is the result of recent evolution. IUBMB Life 59: 436-440.

Felger I, Irion A, Steiger S, Beck HP 1999. Genotypes of merozoite surface protein 2 of Plasmodium falciparum in Tanzania. Trans R Soc Trop Med Hyg 93 (Suppl. 1): 3-9.
Ferreira A, Balla J, Jeney V, Balla G, Soares MP 2008. A central role for free heme in the pathogenesis of severe malaria: the missing link? J Mol Med (Berl) 86: 1097-1111.

Ferreira A, Marguti I, Bechmann I, Jeney V, Chora A, Palha NR, Rebelo S, Henri A, Beuzard Y, Soares MP 2011. Sickle hemoglobin confers tolerance to Plasmodium infection. Cell 145: 398-409.

Fesel C, Goulart LF, Silva Neto A, Coelho A, Fontes CJF, Braga EM, Vaz NM 2005. Increased polyclonal immunoglobulin reactivity toward human and bacterial proteins is associated with clinical protection in human Plasmodium infection. Malar J 4: 5.

Foo LC, Rekhraj V, Chiang GL, Mak JW 1992. Ovalocytosis protects against severe malaria parasitemia in the Malayan aborigines. $\mathrm{Am}$ J Trop Med Hyg 47: 271-275.

French N, Nakiyingi J, Lugada E, Watera C, Whitworth JA, Gilks CF 2001. Increasing rates of malarial fever with deteriorating immune status in HIV-1-infected Ugandan adults. AIDS 15: 899-906.

Friesen J, Silvie O, Putrianti ED, Hafalla JCR, Matuschewski K, Borrmann S 2010. Natural immunization against malaria: causal prophylaxis with antibiotics. Sci Transl Med 2: 40ra49.

Fugikaha E, Fornazari PA, Penhalbel R de SR, Lorenzetti A, Maroso RD, Amoras JT, Saraiva AS, Silva RU da, Bonini-Domingos CR, Mattos LC de, Rossit ARB, Cavasini CE, Machado RLD 2007. Molecular screening of Plasmodium sp. asymptomatic carriers among transfusion centers from Brazilian Amazon Region. Rev Inst Med Trop Sao Paulo 49: 1-4.

Gonçalves RM, Salmazi KC, Santos BAN, Bastos MS, Rocha SC, Boscardin SB, Silber AM, Kallás EG, Ferreira MU, Scopel KKG 2010. $\mathrm{CD} 4^{+} \mathrm{CD} 25^{+} \mathrm{Foxp}^{+}$regulatory T-cells, dendritic cells, and circulating cytokines in uncomplicated malaria: do different parasite species elicit similar host responses? Infect Immun 78: 4763-4772.

Gonçalves RM, Scopel KKG, Bastos MS, Ferreira MU 2012. Cytokine balance in human malaria: does Plasmodium vivax elicit more inflammatory responses than Plasmodium falciparum? PLoS One 7: e44394.

Gouagna LC, Ferguson HM, Okech BA, Killeen GF, Kabiru EW, Beier JC, Githure JI, Yan G 2004. Plasmodium falciparum malaria disease manifestations in humans and transmission to Anopheles gambiae: a field study in Western Kenya. Parasitology 128: 235-243.

Gozzelino R, Andrade BB, Larsen R, Luz NF, Vanoaica L, Seixas E, Coutinho A, Cardoso S, Rebelo S, Poli M, Barral-Netto M, Darshan D, Kühn LC, Soares MP 2012. Metabolic adaptation to tissue iron overload confers tolerance to malaria. Cell Host Microbe 12: 693-704.

Gozzelino R, Jeney V, Soares MP 2010. Mechanisms of cell protection by heme oxygenase-1. Annu Rev Pharmacol Toxicol 50: 323-354.

Gozzelino R, Soares MP 2011. Heme sensitization to TNF-mediated programmed cell death. Adv Exp Med Biol 691: 211-219.

Hansson HH, Maretty L, Balle C, Goka BQ, Luzon E, Nkrumah FN, Schousboe ML, Rodrigues OP, Bygbjerg IC, Kurtzhals JAL, Alifrangis M, Hempel C 2015. Polymorphisms in the haem oxygenase-1 promoter are not associated with severity of Plasmodium falciparum malaria in Ghanaian children. Malar J 14: 153.

Hebbel RP, Morgan WT, Eaton JW, Hedlund BE 1988. Accelerated autoxidation and heme loss due to instability of sickle hemoglobin. Proc Natl Acad Sci USA 85: 237-241.

Hoffman SL, Doolan DL 2000. Malaria vaccines-targeting infected hepatocytes. Nat Med 6: 1218-1219.

Jagannathan P, Eccles-James I, Bowen K, Nankya F, Auma A, Wamala S, Ebusu C, Muhindo MK, Arinaitwe E, Briggs J, Greenhouse B, Tappero JW, Kamya MR, Dorsey G, Feeney ME 2014. IFN $\gamma /$ 
IL-10 co-producing cells dominate the CD4 response to malaria in highly exposed children. PLoS Pathog 10: e1003864.

Jallow M, Teo YY, Small KS, Rockett KA, Deloukas P, Clark TG, Kivinen K, Bojang KA, Conway DJ, Pinder M, Sirugo G, SisayJoof F, Usen S, Auburn S, Bumpstead SJ, Campino S, Coffey A, Dunham A, Fry AE, Green A, Gwilliam R, Hunt SE, Inouye M, Jeffreys AE, Mendy A, Palotie A, Potter S, Ragoussis J, Rogers J, Rowlands K, Somaskantharajah E, Whittaker P, Widden C, Donnelly P, Howie B, Marchini J, Morris A, SanJoaquin M, Achidi EA, Agbenyega T, Allen A, Amodu O, Corran P, Djimde A, Dolo A, Doumbo OK, Drakeley C, Dunstan S, Evans J, Farrar J, Fernando D, Hien TT, Horstmann RD, Ibrahim M, Karunaweera N, Kokwaro G, Koram KA, Lemnge M, Makani J, Marsh K, Michon P, Modiano D, Molyneux ME, Mueller I, Parker M, Peshu N, Plowe C V, Puijalon O, Reeder J, Reyburn H, Riley EM, Sakuntabhai A, Singhasivanon P, Sirima S, Tall A, Taylor TE, Thera M, Troye-Blomberg M, Williams TN, Wilson M, Kwiatkowski DP 2009. Genome-wide and fine-resolution association analysis of malaria in West Africa. Nat Genet 41: 657-665.

Jayavanth S, Singh M 2003. Artificial neural network analysis of malaria severity through aggregation and deformability parameters of erythrocytes. Clin Hemorheol Microcirc 29: 457-468.

Joos C, Marrama L, Polson HEJ, Corre S, Diatta A-M, Diouf B, Trape J-F, Tall A, Longacre S, Perraut R 2010. Clinical protection from falciparum malaria correlates with neutrophil respiratory bursts induced by merozoites opsonized with human serum antibodies. PLoS One 5: e9871.

Kapelski S, Klockenbring T, Fischer R, Barth S, Fendel R 2014. Assessment of the neutrophilic antibody-dependent respiratory burst (ADRB) response to Plasmodium falciparum. J Leukoc Biol 96: 1131-1142.

Karunaweera ND, Grau GE, Gamage P, Carter R, Mendis KN 1992. Dynamics of fever and serum levels of tumor necrosis factor are closely associated during clinical paroxysms in Plasmodium vivax malaria. Proc Natl Acad Sci USA 89: 3200-3203.

Kho S, Marfurt J, Noviyanti R, Kusuma A, Piera KA, Burdam FH, Kenangalem E, Lampah DA, Engwerda CR, Poespoprodjo JR, Price RN, Anstey NM, Minigo G, Woodberry T 2015. Preserved dendritic cell HLA-DR expression and reduced regulatory T cell activation in asymptomatic Plasmodium falciparum and $P$. vivax infection. Infect Immun 83: 3224-3232.

Kiang R, Adimi F, Soika V, Nigro J, Singhasivanon P, Sirichaisinthop J, Leemingsawat S, Apiwathnasorn C, Looareesuwan S 2006. Meteorological, environmental remote sensing and neural network analysis of the epidemiology of malaria transmission in Thailand. Geospat Health 1: 71-84.

Kinyanjui SM, Mwangi T, Bull PC, Newbold CI, Marsh K 2004. Protection against clinical malaria by heterologous immunoglobulin $\mathrm{G}$ antibodies against malaria-infected erythrocyte variant surface antigens requires interaction with asymptomatic infections. J Infect Dis 190: 1527-1533.

Koukouikila-Koussounda F, Ntoumi F, Ndounga M, Tong H V, Abena A-A, Velavan TP 2013. Genetic evidence of regulatory gene variants of the STAT6, IL10R and FOXP3 locus as a susceptibility factor in uncomplicated malaria and parasitaemia in Congolese children. Malar J 12: 9.

Kristiansen M, Graversen JH, Jacobsen C, Sonne O, Hoffman HJ, Law SK, Moestrup SK 2001. Identification of the haemoglobin scavenger receptor. Nature 409: 198-201.

Kublin JG, Patnaik P, Jere CS, Miller WC, Hoffman IF, Chimbiya N, Pendame R, Taylor TE, Molyneux ME 2005. Effect of Plasmodium falciparum malaria on concentration of HIV-1-RNA in the blood of adults in rural Malawi: a prospective cohort study. Lancet 365: 233-240.
Kuesap J, Hirayama K, Kikuchi M, Ruangweerayut R, Na-Bangchang K 2010. Study on association between genetic polymorphisms of haem oxygenase-1, tumour necrosis factor, cadmium exposure and malaria pathogenicity and severity. Malar J 9: 260.

Kwiatkowski D 2000. Genetic susceptibility to malaria getting complex. Curr Opin Genet. Dev 10: 320-324.

Kwiatkowski D, Hill A V, Sambou I, Twumasi P, Castracane J, Manogue KR, Cerami A, Brewster DR, Greenwood BM 1990. TNF concentration in fatal cerebral, non-fatal cerebral, and uncomplicated Plasmodium falciparum malaria. Lancet 336: 1201-1204.

Ladeia-Andrade S, Ferreira MU, Carvalho ME de, Curado I, Coura JR 2009. Age-dependent acquisition of protective immunity to malaria in riverine populations of the Amazon Basin of Brazil. Am J Trop Med Hyg 80: 452-459.

Laishram DD, Sutton PL, Nanda N, Sharma VL, Sobti RC, Carlton JM, Joshi H 2012. The complexities of malaria disease manifestations with a focus on asymptomatic malaria. Malar J 11: 29.

Lemaitre M, Watier L, Briand V, Garcia A, Hesran JY Le, Cot M 2014. Coinfection with Plasmodium falciparum and Schistosoma haematobium: additional evidence of the protective effect of schistosomiasis on malaria in Senegalese children. Am J Trop Med Hyg 90: 329-334.

Lindblade KA, Steinhardt L, Samuels A, Kachur SP, Slutsker L 2013. The silent threat: asymptomatic parasitemia and malaria transmission. Expert Rev Anti Infect Ther 11: 623-639.

Martin SK, Miller LH, Hicks CU, David-West A, Ugbode C, Deane M 1979. Frequency of blood group antigens in Nigerian children with falciparum malaria. Trans $R$ Soc Trop. Med Hyg 73: 216-218.

Medzhitov R, Schneider DS, Soares MP 2012. Disease tolerance as a defense strategy. Science 335: 936-941.

Mendonça VR, Souza LC, Garcia GC, Magalhães BM, Lacerda MV, Andrade BB, Gonçalves MS, Barral-Netto M 2014. DDX39B (BAT1), TNF and IL6 gene polymorphisms and association with clinical outcomes of patients with Plasmodium vivax malaria. Malar J 13: 278.

Mendonça VRR de, Goncalves MS, Barral-Netto M 2012a. The host genetic diversity in malaria infection. J Trop Med 2012: 940616.

Mendonça VRR, Luz NF, Santos NJG, Borges VM, Gonçalves MS, Andrade BB, Barral-Netto M 2012b. Association between the haptoglobin and heme oxygenase 1 genetic profiles and soluble CD163 in susceptibility to and severity of human malaria. Infect Immun 80: 1445-1454.

Mendonça VRR, Queiroz ATL, Lopes FM, Andrade BB, Barral-Netto M 2013. Networking the host immune response in Plasmodium vivax malaria. Malar J 12: 69.

Milet J, Nuel G, Watier L, Courtin D, Slaoui Y, Senghor P, Migot-Nabias F, Gaye O, Garcia A 2010. Genome wide linkage study, using a 250K SNP map, of Plasmodium falciparum infection and mild malaria attack in a Senegalese population. PLoS One 5: e11616.

Miller YI, Shaklai N 1999. Kinetics of hemin distribution in plasma reveals its role in lipoprotein oxidation. Biochim Biophys Acta 1454: 153-164.

Minigo G, Woodberry T, Piera KA, Salwati E, Tjitra E, Kenangalem E, Price RN, Engwerda CR, Anstey NM, Plebanski M 2009. Parasite-dependent expansion of TNF receptor II-positive regulatory T-cells with enhanced suppressive activity in adults with severe malaria. PLoS Pathog 5: e1000402.

Mombo L-E, Ntoumi F, Bisseye C, Ossari S, Lu CY, Nagel RL, Krishnamoorthy R 2003. Human genetic polymorphisms and asymptomatic Plasmodium falciparum malaria in Gabonese schoolchildren. Am J Trop Med Hyg 68: 186-190. 
Moormann AM, Sumba PO, Chelimo K, Fang H, Tisch DJ, Dent AE, John CC, Long CA, Vulule J, Kazura JW 2013. Humoral and cellular immunity to Plasmodium falciparum merozoite surface protein 1 and protection from infection with blood-stage parasites. J Infect Dis 208: 149-158.

Mordmüller BG, Metzger WG, Juillard P, Brinkman BM, Verweij CL, Grau GE, Kremsner PG 1997. Tumor necrosis factor in Plasmodium falciparum malaria: high plasma level is associated with fever, but high production capacity is associated with rapid fever clearance. Eur Cytokine Netw 8: 29-35.

Najem GR, Sulzer AJ 2003. Transfusion-induced malaria from an asymptomatic carrier. Transfusion 16: 473-476.

Ntoumi F, Contamin H, Rogier C, Bonnefoy S, Trape JF, MercereauPuijalon O 1995. Age-dependent carriage of multiple Plasmodium falciparum merozoite surface antigen-2 alleles in asymptomatic malaria infections. Am J Trop Med Hyg 52: 81-88.

Nussenzweig RS, Vanderberg J, Most H, Orton C 1967. Protective immunity produced by the injection of $\mathrm{x}$-irradiated sporozoites of Plasmodium berghei. Nature 216: 160-162.

Olotu A, Moris P, Mwacharo J, Vekemans J, Kimani D, Janssens M, Kai O, Jongert E, Lievens M, Leach A, Villafana T, Savarese B, Marsh K, Cohen J, Bejon P 2011. Circumsporozoite-specific T-cell responses in children vaccinated with RTS,S/AS01E and protection against $P$. falciparum clinical malaria. PLoS One 6: e25786.

Ong'echa JM, Davenport GC, Vulule JM, Hittner JB, Perkins DJ 2011. Identification of inflammatory biomarkers for pediatric malarial anemia severity using novel statistical methods. Infect Immun 79: 4674-4680.

Oppenheimer SJ, Higgs DR, Weatherall DJ, Barker J, Spark RA 1984. Alpha thalassaemia in Papua New Guinea. Lancet 1: 424-426.

Overstreet MG, Cockburn IA, Chen Y-C, Zavala F 2008. Protective CD8 T-cells against Plasmodium liver stages: immunobiology of an "unnatural" immune response. Immunol Rev 225: 272-283.

Palm NW, Medzhitov R 2009. Pattern recognition receptors and control of adaptive immunity. Immunol Rev 227: 221-233.

Pamplona A, Ferreira A, Balla J, Jeney V, Balla G, Epiphanio S, Chora A, Rodrigues CD, Gregoire IP, Cunha-Rodrigues M, Portugal S, Soares MP, Mota MM 2007. Heme oxygenase-1 and carbon monoxide suppress the pathogenesis of experimental cerebral malaria. Nat Med 13: 703-710.

Paoli M, Anderson BF, Baker HM, Morgan WT, Smith A, Baker EN 1999. Crystal structure of hemopexin reveals a novel high-affinity heme site formed between two beta-propeller domains. Nat Struct Biol 6: 926-931.

Perdijk O, Arama C, Giusti P, Maiga B, Troye-Blomberg M, Dolo A, Doumbo O, Persson J-O, Boström S 2013. Haptoglobin phenotype prevalence and cytokine profiles during Plasmodium falciparum infection in Dogon and Fulani ethnic groups living in Mali. Malar J 12: 432.

Perkins DJ, Hittner JB, Mwaikambo ED, Granger DL, Weinberg JB, Anstey NM 2005. Impaired systemic production of prostaglandin E2 in children with cerebral malaria. J Infect Dis 191: 1548-1557.

Philippidis P, Mason JC, Evans BJ, Nadra I, Taylor KM, Haskard DO, Landis RC 2004. Hemoglobin scavenger receptor CD163 mediates interleukin-10 release and heme oxygenase-1 synthesis: antiinflammatory monocyte-macrophage responses in vitro, in resolving skin blisters in vivo, and after cardiopulmonary bypass surgery. Circ Res 94: 119-126.

Portugal S, Doumtabe D, Traore B, Miller LH, Troye-Blomberg M, Doumbo OK, Dolo A, Pierce SK, Crompton PD 2012. B-cell analysis of ethnic groups in Mali with differential susceptibility to malaria. Malar J 11: 162.
Portugal S, Tipton CM, Sohn H, Kone Y, Wang J, Li S, Skinner J, Virtaneva K, Sturdevant DE, Porcella SF, Doumbo OK, Doumbo S, Kayentao K, Ongoiba A, Traore B, Sanz I, Pierce SK, Crompton PD 2015. Malaria-associated atypical memory B-cells exhibit markedly reduced B-cell receptor signaling and effector function. Elife doi: 10.7554/eLife.07218.

Powrie F, Read S, Mottet C, Uhlig H, Maloy K 2003. Control of immune pathology by regulatory T-cells. Novartis Found Symp 252: 92-98; discussion 98-105, 106-114.

Quaye IK 2008. Haptoglobin, inflammation and disease. Trans R Soc Trop Med Hyg 102: 735-742.

Rihet P, Traoré Y, Abel L, Aucan C, Traoré-Leroux T, Fumoux F 1998. Malaria in humans: Plasmodium falciparum blood infection levels are linked to chromosome 5q31-q33. Am J Hum Genet 63: 498-505.

Rodrigues M, Nussenzweig RS, Zavala F 1993. The relative contribution of antibodies, $\mathrm{CD}^{+}$and $\mathrm{CD} 8^{+} \mathrm{T}$-cells to sporozoite-induced protection against malaria. Immunology 80: 1-5.

Roestenberg M, McCall M, Hopman J, Wiersma J, Luty AJF, van Gemert GJ, van de Vegte-Bolmer M, van Schaijk B, Teelen K, Arens T, Spaarman L, Mast Q de, Roeffen W, Snounou G, Rénia L, van der Ven A, Hermsen CC, Sauerwein R 2009. Protection against a malaria challenge by sporozoite inoculation. $N$ Engl J Med 361: 468-477.

Roestenberg M, Teirlinck AC, McCall MBB, Teelen K, Makamdop KN, Wiersma J, Arens T, Beckers P, van Gemert G, van der Vegte-Bolmer M, van der Ven AJAM, Luty AJF, Hermsen CC, Sauerwein RW 2011. Long-term protection against malaria after experimental sporozoite inoculation: an open-label follow-up study. Lancet 377: 1770-1776.

Romero P, Maryanski JL, Corradin G, Nussenzweig RS, Nussenzweig V, Zavala F 1989. Cloned cytotoxic T-cells recognize an epitope in the circumsporozoite protein and protect against malaria. Nature 341: 323-326.

Rono J, Osier FHA, Olsson D, Montgomery S, Mhoja L, Rooth I, Marsh K, Färnert A 2013. Breadth of anti-merozoite antibody responses is associated with the genetic diversity of asymptomatic Plasmodium falciparum infections and protection against clinical malaria. Clin Infect Dis 57: 1409-1416.

Sabchareon A, Burnouf T, Ouattara D, Attanath P, Bouharoun-Tayoun H, Chantavanich P, Foucault C, Chongsuphajaisiddhi T, Druilhe P 1991. Parasitologic and clinical human response to immunoglobulin administration in falciparum malaria. Am J Trop Med Hyg 45: 297-308.

Sagna AB, Gaayeb L, Sarr JB, Senghor S, Poinsignon A, Boutouaba-Combe S, Schacht A-M, Hermann E, Faye N, Remoue F, Riveau G 2013. Plasmodium falciparum infection during dry season: IgG responses to Anopheles gambiae salivary gSG6-P1 peptide as sensitive biomarker for malaria risk in Northern Senegal. Malar J 12: 301.

Schmidt NW, Podyminogin RL, Butler NS, Badovinac VP, Tucker BJ, Bahjat KS, Lauer P, Reyes-Sandoval A, Hutchings CL, Moore AC, Gilbert SC, Hill A V, Bartholomay LC, Harty JT 2008. Memory CD8 T-cell responses exceeding a large but definable threshold provide long-term immunity to malaria. Proc Natl Acad Sci USA 105: 14017-14022.

Schneider P, Bousema JT, Gouagna LC, Otieno S, Vegte-Bolmer M van de, Omar SA, Sauerwein RW 2007. Submicroscopic Plasmodium falciparum gametocyte densities frequently result in mosquito infection. Am J Trop Med Hyg 76: 470-474.

Schofield L, Villaquiran J, Ferreira A, Schellekens H, Nussenzweig R, Nussenzweig V 1987. Gamma interferon, $\mathrm{CD}^{+}$T-cells and antibodies required for immunity to malaria sporozoites. Nature 330: 664-666. 
Scuracchio P, Vieira SD, Dourado DA, Bueno LM, Colella R, RamosSanchez EM, Lima GFMC, Inoue J, Sanchez MCA, Santi SM Di 2011. Transfusion-transmitted malaria: case report of asymptomatic donor harboring Plasmodium malariae. Rev Inst Med Trop Sao Paulo 53: 55-59.

Shimizu H, Tamam M, Soemantri A, Ishida T 2005. Glucose-6-phosphate dehydrogenase deficiency and Southeast Asian ovalocytosis in asymptomatic Plasmodium carriers in Sumba island, Indonesia. J Hum Genet 50: 420-424.

Sikora M, Laayouni H, Menendez C, Mayor A, Bardaji A, Sigauque B, Netea MG, Casals F, Bertranpetit J 2011. A targeted association study of immunity genes and networks suggests novel associations with placental malaria infection. PLoS One 6: e24996.

Smith T, Felger I, Tanner M, Beck HP 1999. Premunition in Plasmodium falciparum infection: insights from the epidemiology of multiple infections. Trans R Soc Trop Med Hyg 93 (Suppl. 1): 59-64.

Stephens R, Albano FR, Quin S, Pascal BJ, Harrison V, Stockinger B, Kioussis D, Weltzien H-U, Langhorne J 2005. Malaria-specific transgenic CD4(+) T-cells protect immunodeficient mice from lethal infection and demonstrate requirement for a protective threshold of antibody production for parasite clearance. Blood 106: 1676-1684.

Stephens R, Langhorne J 2010. Effector memory Th1 CD4 T-cells are maintained in a mouse model of chronic malaria. PLoS Pathog 6: e1001208.

Tada MS, Ferreira RGM, Katsuragawa TH, Martha RCD, Costa JDAN, Albrecht L, Wunderlich G, da Silva LHP 2012. Asymptomatic infection with Plasmodium falciparum and Plasmodium vivax in the Brazilian Amazon Basin: to treat or not to treat? Mem Inst Oswaldo Cruz 107: 621-629.

Taylor SM, Cerami C, Fairhurst RM 2013. Hemoglobinopathies: slicing the Gordian knot of Plasmodium falciparum malaria pathogenesis. PLoS Pathog 9: e1003327.

Thornton AM, Shevach EM 2000. Suppressor effector function of $\mathrm{CD} 4{ }^{+} \mathrm{CD} 25^{+}$immunoregulatory T-cells is antigen nonspecific. $J$ Immunol 164: 183-190.

Timmann C, Evans JA, König IR, Kleensang A, Rüschendorf F, Lenzen J, Sievertsen J, Becker C, Enuameh Y, Kwakye KO, Opoku E, Browne ENL, Ziegler A, Nürnberg P, Horstmann RD 2007. Genome-wide linkage analysis of malaria infection intensity and mild disease. PLoS Genet 3: e48.

Timmann C, Thye T, Vens M, Evans J, May J, Ehmen C, Sievertsen J, Muntau B, Ruge G, Loag W, Ansong D, Antwi S, Asafo-Adjei E, Nguah SB, Kwakye KO, Akoto AOY, Sylverken J, Brendel M, Schuldt K, Loley C, Franke A, Meyer CG, Agbenyega T, Ziegler A, Horstmann RD 2012. Genome-wide association study indicates two novel resistance loci for severe malaria. Nature 489: 443-446.

Tolosano E, Fagoonee S, Morello N, Vinchi F, Fiorito V 2010. Heme scavenging and the other facets of hemopexin. Antioxid Redox Signal 12: 305-320.

Tran TM, Li S, Doumbo S, Doumtabe D, Huang C-Y, Dia S, Bathily A, Sangala J, Kone Y, Traore A, Niangaly M, Dara C, Kayentao K, Ongoiba A, Doumbo OK, Traore B, Crompton PD 2013. An intensive longitudinal cohort study of Malian children and adults reveals no evidence of acquired immunity to Plasmodium falciparum infection. Clin Infect Dis 57: 40-47.
Tran TM, Samal B, Kirkness E, Crompton PD 2012. Systems immunology of human malaria. Trends Parasitol 28: 248-257.

Trape JF, Rogier C, Konate L, Diagne N, Bouganali H, Canque B, Legros F, Badji A, Ndiaye G, Ndiaye P 1994. The Dielmo Project: a longitudinal study of natural malaria infection and the mechanisms of protective immunity in a community living in a holoendemic area of Senegal. Am J Trop Med Hyg 51: 123-137.

Tsuji M, Bergmann CC, Takita-Sonoda Y, Murata K, Rodrigues EG, Nussenzweig RS, Zavala F 1998. Recombinant Sindbis viruses expressing a cytotoxic T-lymphocyte epitope of a malaria parasite or of influenza virus elicit protection against the corresponding pathogen in mice. $J$ Virol 72: 6907-6910.

Verhoeff FH, Brabin BJ, Hart CA, Chimsuku L, Kazembe P, Broadhead RL 1999. Increased prevalence of malaria in HIV-infected pregnant women and its implications for malaria control. Trop Med Int Health 4: 5-12.

Villasis E, Lopez-Perez M, Torres K, Gamboa D, Neyra V, Bendezu J, Tricoche N, Lobo C, Vinetz JM, Lustigman S 2012. Anti-Plasmodium falciparum invasion ligand antibodies in a low malaria transmission region, Loreto, Peru. Malar J 11: 361.

Walther M, Caul A De, Aka P, Njie M, Amambua-Ngwa A, Walther B, Predazzi IM, Cunnington A, Deininger S, Takem EN, Ebonyi A, Weis S, Walton R, Rowland-Jones S, Sirugo G, Williams SM, Conway DJ 2012. HMOX1 gene promoter alleles and high HO-1 levels are associated with severe malaria in Gambian children. PLoS Pathog 8: e1002579.

Walther M, Tongren JE, Andrews L, Korbel D, King E, Fletcher H, Andersen RF, Bejon P, Thompson F, Dunachie SJ, Edele F, de Souza JB, Sinden RE, Gilbert SC, Riley EM, Hill AVS 2005. Upregulation of TGF-beta, FOXP3, and $\mathrm{CD}^{+} \mathrm{CD}^{+} 5^{+}$regulatory T-cells correlates with more rapid parasite growth in human malaria infection. Immunity 23: 287-296.

Wammes LJ, Wiria AE, Toenhake CG, Hamid F, Liu KY, Suryani H, Kaisar MMM, Verweij JJ, Sartono E, Supali T, Smits HH, Luty AJ, Yazdanbakhsh M 2013. Asymptomatic plasmodial infection is associated with increased tumor necrosis factor receptor II-expressing regulatory T-cells and suppressed type 2 immune responses. J Infect Dis 207: 1590-1599.

Weiss GE, Crompton PD, Li S, Walsh LA, Moir S, Traore B, Kayentao K, Ongoiba A, Doumbo OK, Pierce SK 2009. Atypical memory $\mathrm{B}$-cells are greatly expanded in individuals living in a malariaendemic area. J Immunol 183: 2176-2182.

White NJ 2008. The role of anti-malarial drugs in eliminating malaria. Malar J 7 (Suppl.1): S8.

Whitworth J, Morgan D, Quigley M, Smith A, Mayanja B, Eotu H, Omoding N, Okongo M, Malamba S, Ojwiya A 2000. Effect of HIV-1 and increasing immunosuppression on malaria parasitaemia and clinical episodes in adults in rural Uganda: a cohort study. Lancet 356: 1051-1056.

WHO - World Health Organization 2014. World Malaria Report 2014. Available from: who.int/malaria/publications/world_malaria_report_2014/en/.

Wykes MN, Liu XQ, Beattie L, Stanisic DI, Stacey KJ, Smyth MJ, Thomas R, Good MF 2007. Plasmodium strain determines dendritic cell function essential for survival from malaria. PLoS Pathog 3: e96. 